\title{
Piotr Oleksyk
}

Uniwersytet Ekonomiczny we Wrocławiu

e-mail: piotr.oleksyk@ue.wroc.pl

\section{AUDYT BEZPIECZEŃSTWA FINANSOWEGO}

\section{FINANCIAL SAFETY AUDIT}

DOI: $10.15611 /$ pn.2018.521.12

JEL Classification: M40, M42, M49

\begin{abstract}
Streszczenie: Celem artykułu jest wskazanie kluczowych czynników zapewniających eliminację zagrożeń bezpieczeństwa finansowego jednostki. Podwyższanie poziomu bezpieczeństwa finansowego powinno opierać się na dwóch ważnych elementach: identyfikacji obszarów zagrożonych oraz eliminacji czynników będących przyczynami tych zagrożeń. Istotnym elementem jest opracowanie procedur audytu pozwalających na skuteczną minimalizację ryzyka. Badanie literatury jest punktem wyjścia rozważań. Następnie, wykorzystując wnioskowanie przez analogię oraz metodę dedukcyjną, zaproponowano metodologię przeciwdziałania zagrożeniom. Przeprowadzone przez autora badania stały się podstawą do wyznaczenia modelowej procedury audytu bezpieczeństwa finansowego. Wartością artykułu jest oryginalna propozycja autorskich rozwiązań wspierających zarządzających jednostką gospodarczą w skutecznym eliminowaniu zagrożeń bezpieczeństwa finansowego.
\end{abstract}

Słowa kluczowe: bezpieczeństwo finansowe, funkcja doradcza, metodyka zadania audytowego, ocena ryzyka.

Summary: The purpose of the article is to indicate the key factors ensuring the elimination of threats to the financial safety of the company. The study of literature is the starting point for reflection. Then, using inference by analogy and the deductive method, a proposal for a methodology to counteract threats was proposed. The research carried out by the author became the basis for determining the model procedure of auditing financial security. The value of the article is the original proposition of proprietary solutions supporting managers.

Keywords: financial safety, advisory function, audit task methodology, risk assessment.

\section{Wstęp}

Działalność przedsiębiorstwa jest narażona na wiele zagrożeń. Można je zdefiniować jako bezpośrednie zdarzenia powodujące uszczerbek w majątku przedsiębiorstwa, powstanie obowiązku przyszłej płatności o charakterze sankcyjnym, jak również utratę możliwości osiągnięcia zaplanowanych przychodów. Zagrożeniem może 
być pojedyncze zjawisko lub splot niekorzystnych sytuacji rynkowych, które bezpośrednio lub pośrednio związane są z działalnością przedsiębiorstwa. Większość tych zdarzeń występuje niezależnie od jednostki, a często wbrew woli jej zarządzających. Najbardziej niebezpieczne sytuacje są najczęściej skutkiem świadomych działań konkurentów lub kontrahentów przedsiębiorstwa. Nie należy jednak lekceważyć sytuacji, które są dziełem przypadku.

Zagrożenia powodujące zakłócenie bezpieczeństwa przedsiębiorstwa mogą mieć różny charakter oraz skalę wpływu na jego działalność. Zagrożenia te mogą dotyczyć problemów ekonomicznych, jak i techniczno-organizacyjnych. Jednak skutki ich negatywnego wpływu mają najczęściej wymiar finansowy [Piotrowska 2016, s. 351]. Bezpieczeństwo przedsiębiorstwa należy rozważać na wielu płaszczyznach, z których najważniejszy wymiar dotyczy finansowych aspektów jego działalności. Wdrożenie instrumentów zabezpieczających i mechanizmów kontrolnych, które są opracowane standardowo, bez dopasowania do specyfiki przedsiębiorstwa, nie jest gwarancją wzrostu poziomu bezpieczeństwa finansowego przedsiębiorstwa. Nie wszystkie problemy można rozwiązywać za pomocą wdrażania dodatkowych instrumentów zabezpieczających lub uruchamiania kosztownych procedur prawnych.

Celem artykułu jest wskazanie najważniejszych elementów pracy audytora wewnętrznego wspomagających zapewnienie bezpieczeństwa finansowego. Artykuł składa się z trzech części. W pierwszej zaprezentowano istotę problemu, typowe zagrożenia bezpieczeństwa finansowego w przedsiębiorstwie oraz sposoby ich identyfikacji. W drugiej części omówiono najważniejsze metody oceny poziomu zagrożenia przedsiębiorstwa. W części trzeciej przedstawiono autorską propozycję procedury audytu bezpieczeństwa finansowego w formie typowego zadania audytowego. Wieloaspektowa ocena zagrożeń $\mathrm{w}$ trakcie zadania audytowego jest podstawą do wyznaczenia polityki ograniczania ryzykownych działań, które mogą negatywnie wpłynąć na przyszłą kondycję przedsiębiorstwa.

\section{Zagadnienie bezpieczeństwa finansowego}

Istnieje wiele definicji bezpieczeństwa, z których najbardziej ogólna wskazuje na stan lub sytuację wolne od zagrożeń. Niestety stan, w którym przedsiębiorstwo nie jest narażone na zagrożenia, występuje tylko w rozważaniach teoretycznych. Dlatego bezpieczeństwo finansowe przedsiębiorstwa należy rozumieć jako stan, w którym występują akceptowalne zagrożenia, pozwalające na niezakłóconą działalność. Niezakłócona działalność to taka, która charakteryzuje się zdolnością do rozwoju oraz nieograniczonymi możliwościami zmiany, która odzwierciedla zamierzenia jego właścicieli.

Bezpieczeństwo finansowe przedsiębiorstwa definiowane jest często jako stan wysokiej zdolności do kontynuowania działalności [Belás i in. 2017, s. 79]. Jest również definiowane jako mechanizm, który zapewnia stabilność funkcjonowania przedsiębiorstwa poprzez racjonalne wykorzystanie zasobów przedsiębiorstwa 
oraz wykorzystanie dostępnych instrumentów zabezpieczających [Delas i in. 2015, s. 249]. Bezpieczeństwo finansowe jest ściśle związane z ryzykiem działalności gospodarczej. Podstawowym rodzajem ryzyka jest ryzyko kredytowe (por. [Vivchar 2016, s. 948]), które należy zdefiniować jako zagrożenie utratą należnych środków zaangażowanych w bieżącą działalność. Także inne rodzaje ryzyka, zarówno o charakterze finansowym, jak i niefinansowym, znacząco obniżają poziom bezpieczeństwa finansowego.

Zagrożeniem bezpieczeństwa finansowego przedsiębiorstwa jest uszczuplenie zasobów przedsiębiorstwa, będące skutkiem działań personelu, jak i otoczenia zewnętrznego (por. [Bartoszewicz 2014, s. 39]). Wśród najważniejszych sytuacji znacząco obniżających poziom bezpieczeństwa finansowego należy wymienić:

- utratę kluczowych składników aktywów generujących przychody przedsiębiorstwa (egzekucja lub kradzież),

- niedostateczne zabezpieczenie spływu należności handlowych (ryzyko kredytowe),

- niedostosowanie poziomu cen i wielkości produkcji do warunków rynkowych (utrata rentowności),

- nadmierne zadłużenie generujące ryzyko płynności,

- niewłaściwe procedury wewnętrzne (ochrona danych, bezpieczeństwo systemu informatycznego, niewłaściwe interpretacje przepisów prawnych).

Obowiązkiem zarządzających jest wdrażanie skutecznych rozwiązań minimalizujących zagrożenia bezpieczeństwa finansowego. Działania takie weryfikowane są przez audytorów wewnętrznych. Efektywny audyt wewnętrzny powinien być skoncentrowany na badaniu adekwatności: zasad, procedur, limitów, zadań i wszelkich mechanizmów stosowanych na wszystkich szczeblach zarządzania w celu zapewnienia (por. [Saunders 2003, s. 21]):

- opłacalności operacji - poprzez efektywne wykorzystanie aktywów i innych zasobów (w celu zabezpieczenia się przed stratą konieczne jest rozpoznawanie, ocena i kontrola finansowych aspektów wszystkich typów transakcji wykonywanych cyklicznie),

- ciągłości realizowanych procesów - wdrażane procedury kontrolne powinny zapewniać ograniczanie zagrożeń utratą reputacji bądź narażeniem przedsiębiorstwa na ryzyko sporów sądowych lub sankcji o charakterze karno-skarbowym,

- zgodności z regulacjami prawnymi - ustanowiony system kontroli wewnętrznej powinien zapewnić, iż całe przedsiębiorstwo przestrzega stosownych przepisów prawa, zasad bezpiecznego działania oraz wewnętrznych zasad polityki, procedur, regulaminów i wypracowanych dobrych praktyk.

Nieumiejętne wdrażanie procedur ograniczania zagrożeń może spowodować nowe zagrożenia, np. wizerunkowe, które staną się powodem utraty dotychczasowych klientów. Nadmiernie rozbudowane procedury kontroli wewnętrznej mogą doprowadzić do paraliżu organizacyjnego i decyzyjnego, co bezpośrednio będzie miało przełożenie na spadek efektywności działalności. Kluczowe jest, aby zarzą- 
dzający jednostką efektywnie zintegrowali przydatne metody ograniczające ryzyko, które nie doprowadzą do pogorszenia jakości prowadzonej działalności. Mechanizmy kontroli wewnętrznej i wynikające z nich obowiązki muszą dotyczyć całej organizacji, bez wyjątków [Winiarska (red.) 2010, s. 124]. Zasada „żadnych wyjątków” musi obowiązywać każdego, bez względu na to, jak ważne stanowisko zajmuje, ile zysków przysparza przedsiębiorstwu. Ogół tych czynności można nazwać podwyższaniem poziomu bezpieczeństwa finansowego. Ocena systemu takich działań jest kluczowym aspektem funkcjonowania audytu wewnętrznego. Niezbędne jest również wypracowanie mechanizmów właściwego pomiaru poziomu bezpieczeństwa finansowego.

\section{Metodyka oceny bezpieczeństwa finansowego}

Wypracowanie rozwiązań mających na celu kompleksowe szacowanie poziomu bezpieczeństwa finansowego powinno być podstawą ciągłej współpracy pomiędzy audytorem a najwyższym kierownictwem przedsiębiorstwa. Zarządzający przedsiębiorstwem powinni dążyć do przygotowania procedur, które kompleksowo obejmą wszystkie rodzaje ryzyka i pozwolą na właściwe podjęcie decyzji. Wszystkie rodzaje ryzyka powinny być w centrum zainteresowania audytora wewnętrznego, jednak kluczowe znaczenie ma bieżące ograniczanie ryzyka kredytowego, przejawiającego się w postaci nieściągalności należności, które bezpośrednio związane jest z zarządzaniem płynnością.

Podstawą wartościowej informacji sprawozdawczej dla podwyższania poziomu bezpieczeństwa finansowego jest wielkość zapotrzebowania na środki pieniężne, zawierająca dane o wysokości ewentualnej nadwyżki lub deficytu środków pieniężnych [Nita 2013, s. 464]. Rzetelna ocena poziomu ryzyka kredytowego, w tym zwłaszcza identyfikacja podstawowych problemów związanych z niewłaściwym spływem należności handlowych, ma kluczowe znaczenie dla oceny zarządzania płynnością. Analizę płynności opiera się na szacowaniu zdolności do spłaty zadłużenia, natomiast ważne jest, aby ustalać i nie przekraczać podstawowych progów zadłużeniowych. Poza zadłużeniem w analizie płynności należy przeprowadzić analizy w zakresie właściwego zarządzania środkami pieniężnymi w aspekcie wystarczalności tych środków w kolejnych fazach spłaty kluczowych zobowiązań. Bezpieczeństwo finansowe często utożsamiane jest $\mathrm{z}$ wielkością nadwyżki wolnych środków pieniężnych [Bossert, D’Ambrosio 2009, s. 2] pozostających do dyspozycji zarządzających.

Bardzo pomocnym narzędziem są wewnętrzne prognozy zarządcze. Prognostyczna sprawozdawczość wewnętrzna jest niezbędna do skutecznego zarządzania bezpieczeństwem finansowym przedsiębiorstwa. Pozwala audytorowi na spojrzenie na przyszłą sytuację przedsiębiorstwa. Przede wszystkim umożliwia rozpoznanie przyszłych warunków, w jakich będzie funkcjonować przedsiębiorstwo. Prognoza finansowa jest wyłącznie niepewną, ale akceptowalną wersją przyszłości przedsię- 
biorstwa. Konieczne jest również wyznaczenie kontekstowo specyficznych parametrów prognostycznych, uwzględniających sygnały płynące $\mathrm{z}$ otoczenia jednostki. Pomimo konieczności indywidualizacji miar pewne szablonowe wskaźniki powinny być wykorzystywane w szacowaniu poziomu bezpieczeństwa finansowego. Wśród uniwersalnych mierników należy wskazać następujące [Kowalak 2017, s. 162]:

- wskaźniki rentowności: kapitałów, sprzedaży i inwestycji,

- wskaźniki płynności: bieżącej, szybkiej i gotówkowej,

- wskaźniki oceny zadłużenia przedsiębiorstwa,

- strukturę i dynamikę wyników realizowanych w poszczególnych segmentach działalności,

- szacowaną nadwyżkę finansową,

- zapotrzebowanie na wolne środki pieniężne uwzględniające horyzont czasowy rozpatrywanej prognozy decyzyjnej.

Wskazane, uniwersalne wskaźniki związane są z analizą najważniejszych informacji, zawartych w szeroko rozumianym raportowaniu zarządczym. Wykorzystując dotychczasowe doświadczenia, należy szacować ewentualne przyszłe straty. Założenie, że straty takie nie wystąpią, jest skutkiem niedostatecznie przeprowadzonego etapu planowania. Niezbędne jest systematyczne przeprowadzanie analizy zagrożeń i wpływu otoczenia zewnętrznego na bezpieczeństwo finansowe. Nawet jeśli zarządzający nie planują żadnych zmian, może pojawić się konieczność przeciwdziałania sytuacji kryzysowej. Kryzys przedsiębiorstwa może zostać wywołany poprzez: niekorzystne zmiany na lokalnym rynku, wykształcenie negatywnych tendencji i zwyczajów rynkowych (również na rynku pracy) lub intensyfikację działań konkurentów, powodującą utratę dotychczasowych klientów.

Ocena poziomu bezpieczeństwa finansowego wypracowywana jest przez zarządzających [Böhme, Nowey 2008, s. 176]. Pomocna jest w tym przypadku analiza porównawcza. Najczęściej podejmuje się próby porównania z tzw. wielkościami wzorcowymi. Nie jest to jednak rozwiązanie idealne, ponieważ nie uwzględnia specyfiki branży, potencjału obszaru działania jednostki oraz specyficznych uwarunkowań wewnętrznych. Indywidualny charakter każdej jednostki gospodarczej nie usprawiedliwia jednak możliwości zaniechania analizy porównawczych. Uzupełnieniem kluczowych mierników związanych z bezpieczeństwem finansowym każdego przyszłego działania jest badanie efektywności oparte na wynikach możliwych do osiągnięcia.

Rola audytora $\mathrm{w}$ procesie oceny poziomu bezpieczeństwa finansowego jest kluczowa. Konieczne jest, aby na bieżąco oceniać skutki wszystkich działań zarządzających przedsiębiorstwem. Audytor powinien badać stan przygotowania przedsiębiorstwa na negatywne skutki zarówno o charakterze finansowym, jak i operacyjnym [Tomaszkiewicz 2010, s. 112]. W obszarze zainteresowań audytora powinno być badanie przygotowania przedsiębiorstwa na potencjalne zagrożenia wynikające ze zdarzeń operacyjnych. Przygotowanie to powinno przejawiać się we właściwej identyfikacji i wycenie przyszłych strat. Ważne jest, żeby kontrolować, 
czy zarządzający przedsiębiorstwem uwzględniają wpływ takich strat na poziom płynności i przyszłego zadłużenia przedsiębiorstwa.

\section{Przykładowa procedura audytu bezpieczeństwa finansowego}

Zadanie audytowe mające na celu zbadanie bezpieczeństwa finansowego powinno być stałym elementem planu pracy audytora wewnętrznego. Nie jest to zadanie proste i możliwe do przeprowadzenia w krótkim okresie. Z uwagi na fakt wieloaspektowego zagrożenia bezpieczeństwa finansowego również procedura audytu powinna zawierać różnorodne metody i techniki badawcze. Kluczowym elementem jest dobór właściwych mierników o charakterze finansowym. Należy jednak dołączyć metody oceny szacowania przyszłych strat. Dopiero właściwa integracja wskaźników analizy finansowej z prognozą i wyceną negatywnych skutków zdarzeń operacyjnych pozwoli na przygotowanie skutecznej procedury badania audytowego.

Punktem początkowym uniwersalnej procedury audytu bezpieczeństwa finansowego jest ocena przygotowania przedsiębiorstwa na przyszłe zagrożenia. Konieczne jest sprawdzenie adekwatności stosowanych metod prognostycznych. Bardzo często przeprowadzone analizy prognozy przyszłych wyników wskazują na nadmierny poziom ryzyka i konieczność ograniczania ryzykownych operacji. Audytor powinien przygotować właściwy zestaw działań i mierników, których celem jest oszacowanie poziomu bezpieczeństwa finansowego. Przykładowe działania i mierniki zostały zaprezentowane w tab. 1.

Tabela 1. Elementy przykładowej procedury audytu bezpieczeństwa finansowego

\begin{tabular}{|l|l|l|}
\hline Obszar zagrożenia & \multicolumn{1}{|c|}{$\begin{array}{c}\text { Proponowane czynności } \\
\text { audytowe }\end{array}$} & \multicolumn{1}{|c|}{ Proponowane mierniki } \\
\hline \multicolumn{1}{|c|}{$\begin{array}{l}\text { Należności } \\
\text { nieściągalne }\end{array}$} & $\begin{array}{l}\text { Badanie adekwatności procedury } \\
\text { ustalania limitów kredytu kupiec- } \\
\text { kiego. } \\
\text { Badanie adekwatności stosowa- } \\
\text { nych instrumentów zabezpiecze- } \\
\text { niowych. }\end{array}$ & $\begin{array}{l}\text { Udział należności nieściągalnych w pro- } \\
\text { gnozowanych przychodach ze sprzedaży. } \\
\text { Udział otrzymanych poręczeń, gwarancji i } \\
\text { zaliczek w prognozowanych przychodach } \\
\text { ze sprzedaży. }\end{array}$ \\
\hline $\begin{array}{l}\text { Niedostateczny } \\
\text { poziom wolnych } \\
\text { środków } \\
\text { pieniężnych }\end{array}$ & $\begin{array}{l}\text { Badanie adekwatności zaciągania } \\
\text { nowych zobowiązań. } \\
\text { Badanie adekwatności procedur } \\
\text { egzekucyjnych. }\end{array}$ & $\begin{array}{l}\text { Wielkość planowanych rocznych spłat kre- } \\
\text { dytów do wzrostu prognozowanych przy- } \\
\text { chodów ze sprzedaży. } \\
\text { Udział odzyskanych należności w należno- } \\
\text { ściach zagrożonych. }\end{array}$ \\
\hline $\begin{array}{l}\text { Nieefektywne } \\
\text { wykorzystanie } \\
\text { majątku }\end{array}$ & $\begin{array}{l}\text { Badanie indywidualnej rentowno- } \\
\text { ści nowych składników aktywów } \\
\text { trwałych. } \\
\text { Badanie opłacalności alternatyw- } \\
\text { nych form pozyskania składników } \\
\text { np. wypożyczenie). }\end{array}$ & $\begin{array}{l}\text { Wysoḱć planowanych wydatków inwe- } \\
\text { stycyjnch do wzrostu prognozowanych } \\
\text { przychodów ze sprzedaży. }\end{array}$ \\
$\begin{array}{l}\text { Udział kosztów wypożyczenia składnika } \\
\text { w prognozowanych przychodach ze sprze- } \\
\text { daży. }\end{array}$ \\
\hline
\end{tabular}


Tabela 1, cd.

\begin{tabular}{|l|l|l|}
\hline \multicolumn{1}{|c|}{1} & \multicolumn{1}{|c|}{2} & \multicolumn{1}{|c|}{3} \\
\hline $\begin{array}{l}\text { Niewłaściwy } \\
\text { poziom stanów } \\
\text { magazynowych }\end{array}$ & $\begin{array}{l}\text { Badanie zasadności utrzymywa- } \\
\text { nych zapasów materiałowych. } \\
\text { Badanie optymalnej wielkości } \\
\text { produkcji niesprzedanej }\end{array}$ & $\begin{array}{l}\text { Prognozowane wskaźniki obrotowości. } \\
\text { Udział kosztów użyczenia składnika w pro- } \\
\text { gnozowanych przychodach ze sprzedaży }\end{array}$ \\
\hline $\begin{array}{l}\text { Niewłaściwie } \\
\text { zabezpieczone } \\
\text { systemy informa- } \\
\text { tyczne }\end{array}$ & $\begin{array}{l}\text { Badanie adekwatności procedur } \\
\text { bezpieczeństwa systemu informa- } \\
\text { tycznego. }\end{array}$ & $\begin{array}{l}\text { Średni rynkowy koszt przywrócenia pełnej } \\
\text { funkcjonalności systemu informatycznego } \\
\text { w prognozowanym wyniku finansowym } \\
\text { ogółem. } \\
\text { Średni koszt odszkodowania (np. z tytułu } \\
\text { ujawnienia danych wrażliwych) w progno- } \\
\text { zowanym wyniku finansowym ogółem. }\end{array}$ \\
\hline $\begin{array}{l}\text { Niedostatecz- } \\
\text { ne kwalifikacje } \\
\text { zatrudnionych } \\
\text { pracowników }\end{array}$ & $\begin{array}{l}\text { Badanie adekwatności zarządza- } \\
\text { nia tzw. zdarzeniami operacyjny- } \\
\text { mi. } \\
\text { Badanie adekwatności zarządza- } \\
\text { nia ryzykiem przestępstw we- } \\
\text { wnętrznych. }\end{array}$ & $\begin{array}{l}\text { Śdni koszt z tytułu dodatkowych odszko- } \\
\text { dowań w prognozowanym wyniku finanso- } \\
\text { wym ogółem. } \\
\text { Średni koszt z tytułu dokonanych prze- } \\
\text { stępstw pracowniczych w prognozowanym } \\
\text { wyniku finansowym ogółem. }\end{array}$ \\
\hline $\begin{array}{l}\text { Niewłaściwie zor- } \\
\text { ganizowany proces } \\
\text { obsługi prawnej }\end{array}$ & $\begin{array}{l}\text { Badanie adekwatności ogranicza- } \\
\text { nia ryzyka prawnego. }\end{array}$ & $\begin{array}{l}\text { Udział kosztów sporów sądowych w pro- } \\
\text { gnozowanym wyniku finansowym ogółem. }\end{array}$ \\
\hline
\end{tabular}

Źródło: opracowanie własne.

Zaprezentowane w tab. 1 mierniki są podstawą do szacunku poziomu bezpieczeństwa finansowego. Przeprowadzenie tej oceny wymaga od audytora pozyskania danych z zewnątrz przedsiębiorstwa, jak również dokonania oceny realności stosowanych prognoz.

Efektem pracy audytora jest kompleksowa ocena poziomu bezpieczeństwa finansowego. Ze względu na skutki działań podejmowanych w przedsiębiorstwie audytor po przeprowadzonym badaniu powinien dokonać oceny, która powinna mieć charakter:

- atestu dla dotychczasowych działań,

- propozycji eliminacji niewłaściwych działań zachowawczo-ostrożnościowych,

- sugestii konieczności ograniczania ryzyka w wybranych obszarach,

- wskazania rewizji podejścia właścicielskiego,

- alarmu o konieczności głębokiej restrukturyzacji, której brak może doprowadzić do upadłości przedsiębiorstwa.

Przyszłe prace powinny być skoncentrowane na doskonaleniu modelu oceny bezpieczeństwa finansowego poprzez ustalenie ważności obszarów badań audytowych. Konieczne jest ustalenie wag dla wskazanych obszarów zagrożenia. Wypracowanie właściwej oceny powinno mieć charakter ratingowy. 


\section{Zakończenie}

Przeprowadzone badania wskazują, że oszacowanie poziomu bezpieczeństwa finansowego może być kluczowym elementem redukcji ryzyka prowadzonej działalności. Ograniczeniem może być pracochłonność związana z oceną adekwatności procesu prognozowania, które jest ważnym elementem zaproponowanej procedury. Nie jest możliwe całkowite wyeliminowanie przyszłych strat. Dlatego tak ważne jest szacowanie ich wpływu na przyszłe wyniki przedsiębiorstwa.

Wśród pozostałych wniosków wynikających z przeprowadzonych badań należy wymienić:

1. Istnieje wiele zagrożeń bezpieczeństwa finansowego przedsiębiorstwa, a kluczowym zadaniem audytora jest ich właściwa identyfikacja.

2. Ważnym elementem badania audytowego jest ocena adekwatności dostosowania rozwiązań zabezpieczających do specyfiki działalności każdego przedsiębiorstwa.

3. Ocena poziomu bezpieczeństwa finansowego powinna być wspomagana przez analizę porównawczą.

\section{Literatura}

Bartoszewicz A., 2014, Proces zarządzania ryzykiem operacyjnym w banku - studium przypadku, Zeszyty Naukowe Uniwersytetu Szczecińskiego, nr 833, Finanse, Rynki Finansowe, Ubezpieczenia, nr 72, Szczecin.

Belás J., Mišanková M., Schönfeld J., Gavurová B., 2017, Credit risk management: financial safety and sustainability aspects, Journal of Security and Sustainability Issues, vol. 7, no. 1.

Böhme R., Nowey T., 2008, Economic security metrics, [w:] Dependability Metrics, eds I. Eusgeld, F. Freiling, R. Reussner, LNCS, vol. 4909, Springer, Berlin-Heidelberg, s. 176-187.

Bossert W., D’Ambrosio C., 2009, Measuring economic insecurity, ECINEQ Working Papers.

Delas V., Nosova E., Yafinovych O., 2015, Financial security of enterprises, Procedia Economics and Finance, vol. 27, s. 248-266.

Kowalak R., 2017, Rola systemów wczesnego ostrzegania w procesie podejmowania decyzji w restrukturyzacji przedsiębiorstwa, Prace Naukowe Uniwersytetu Ekonomicznego we Wrocławiu, nr 472, Wrocław.

Nita B., 2013, Szacowanie zapotrzebowania na finansowanie rozwoju przedsiębiorstwa za pomoca planowania finansowego, Zeszyty Naukowe Uniwersytetu Szczecińskiego, Finanse, Rynki Finansowe, Ubezpieczenia, nr 61/2, Szczecin.

Piotrowska K., 2016, Etapy procesu innowacyjnego jako obszary ryzyka w audycie wewnętrznym, Zeszyty Naukowe Uniwersytetu Szczecińskiego, Finanse, Rynki Finansowe, Ubezpieczenia, nr 6/1 (84), Szczecin.

Saunders E.J., 2003, Audyt i kontrola wewnętrzna w przedsiębiorstwach, PIKW, Educator, Częstochowa.

Tomaszkiewicz A., 2010, Wartość dodana wnoszona przez audyt wewnętrzny, Acta Universitatis Lodziensis. Folia Oeconomica, nr 244, s. 111-112. 
Vivchar O., 2016, Management system interpreting financial and economic security business in economic processes, IEJME-Mathematics Education, vol. 11(4), s. 947-959.

Winiarska K. (red.), 2010, Kontrola wewnętrzna w jednostkach gospodarczych, Polskie Wydawnictwo Ekonomiczne, Warszawa. 